\title{
Targeting Disaster Aid in Post-Tsunami Sri Lanka
}

Asha Gunawardena and Jean-Marie Baland

$$
\text { CRED - February } 2016
$$




\title{
Targeting Disaster Aid in Post-Tsunami Sri Lanka
}

\author{
Asha Gunawardena and Jean-Marie Baland*
}

In this article we examine the allocation of boats and houses, the two major types of aid made available to tsunami-affected fishery households in Sri Lanka. We investigate the effectiveness of targeting by looking at the distributional impacts and the determinants of allocation of these transfers at the household level. We find that houses were much better targeted than boats in terms of compensating for the losses due to the tsunami. We also find that the ex post distribution of boats is much more unequal than the distribution that prevailed before the tsunami. The reverse is true for the distribution of houses, for which the government took a much more active role.

Key words: Aid targeting, fishery sector, post-disaster development, reconstruction and rehabilitation, Sri Lanka

\section{Introduction}

High population densities and poverty make South Asian countries particularly vulnerable to natural disasters such as floods, droughts or tsunamis. In post-disaster situations, a major role is played by the emergency aid targeted towards the most affected populations. The effectiveness of targeting in these situations has been questioned in the literature, and some authors recommend concentrating efforts on targeting the right recipients instead of increasing the volume of aid (see, for example, Mavrotas, 2009).

The tsunami of 2004 was the largest natural disaster ever recorded in Sri Lanka, with more than 35,000 dead, 20,000 injured and several hundred thousand people displaced (GOSL, 2005). Material costs were also high, with more than 89,000 houses fully destroyed (defined as suffering over $40 \%$ destruction) or damaged (DCS, 2005). The fishery sector was by far the most affected: 5,000 fishermen died, 71,500 fishing households were directly affected, 16,000 boats were lost and 7,000 vessels seriously damaged (ICSFW, 2005, Amarasinghe, 2006). Since $45 \%$ of fishing communities live within 100 metres of the sea, damage to houses was also particularly severe, with $60 \%$ of their houses fully destroyed and $10 \%$ suffering serious damage. In addition, many ecosystems and much coastal infrastructure were either destroyed or irretrievably damaged. In some instances, resettlement to a different location was suggested, creating additional stress and resistance. In this

\footnotetext{
* Researcher, Institute of Policy Studies of Sri Lanka, Columbo, Sri Lanka; Director, CRED (Centre de Recherche en Economie du Développement), Department of Economics, University of Namur, Belgium. We wish to thank the South Asian Network for Development and Environmental Economics and the ERC grant SSD 230290 for financial support.
}

(C) The Authors 2016. Development Policy Review (C) 2016 Overseas Development Institute. Development Policy Review 34 (2) 
article we focus, therefore, on fishing communities, which also constitute the poorest and most marginalised sector of the coastal population, possessing few other assets and limited access to external networks, while also lacking alternative occupation options.

Following the disaster, large amounts of aid were provided to the victims in the form of housing support or boat repairs and replacement. This large rehabilitation effort came from various sources (government, international non-governmental organisations (NGOs), national NGOs, private donors, etc.), but suffered from coordination problems between the government and the NGOs and from the absence of accurate information systems relating to pre-tsunami asset ownership, particularly in the fishing sector (MFAR, 2006). These difficulties were compounded by the lack of local capacity to address the emergency situation. These three problems arise in most emergency relief situations and are by no means specific to this particular situation.

In terms of housing, in 2005 the government started by implementing a buffer zone (at a distance of $100 \mathrm{~m}$ or $200 \mathrm{~m}$ from the sea) ${ }^{1}$ within which no construction was allowed. The government also provided two types of housing assistance for qualifying households (proof of land ownership was required). For those living outside the buffer zone, housing grants and loans were provided through local banks to rebuild houses in the same location. ${ }^{2}$ Families who lived within the buffer zone were resettled on government land and provided with new houses built with donor assistance. ${ }^{3}$ Guidelines over the size of the house (with a minimum of $500 \mathrm{sq} \mathrm{ft}$ ) and the amenities (including water, electricity and sanitation) were set by the Urban Development Authority (UDA). One feature of this policy was a 'house for house' principle according to which the size of the new house was fixed irrespective of the size of the former house (GOSL, 2005). The unavailability of suitable land close to the original villages, the establishment of temporary shelters in the buffer zone and the slow pace of construction forced the government to relax the buffer zone policy in 2006 and to extend assistance to all affected households, irrespective of whether they formally owned land or not. In addition, government and donors proposed new co-financing schemes to build houses as the housing grant provided through the government was inadequate. A new system of direct cash grants was also introduced (IPS, 2006).

Fishing households were also provided with boats and fishing tools. ${ }^{4}$ Boat donations were mostly provided by NGOs, which often saw providing small coastal boats as an attractive, tangible and attention-drawing mode of intervention (MFAR, 2006). Other donors had different objectives, budgets and time constraints, which made co-ordination and planning cumbersome. Moreover, there was no reliable pre-

1. $100 \mathrm{~m}$ for the coastal belt in Kilinochchi, Mannar, Puttlam, Gampha, Kalutara, Galle, Matara and Hambantota districts; $200 \mathrm{~m}$ for the coastal belt in Jaffna, Mulativu, Trincomalee, Batticaloa and Ampara districts.

2. The government of Sri Lanka initially provided housing grants of Rs. $100,000(\$ 1,000)$ for partially damaged and Rs. 250,000 (\$2,500) for 'fully' (defined as more than 40\%) damaged houses.

3. They did, however, retain ownership of their original piece of land.

4. In contrast with other sectors, there were no livelihood training programmes for the fishing sector other than asset replacement (with the exception of a few fishing households who received training in boat repair in Trincomalee).

(C) The Authors 2016. Development Policy Review (C) 2016 Overseas Development Institute. Development Policy Review 34 (2) 
tsunami data to help identify potential beneficiaries. The problem was particularly severe in the traditional fishing sector, as most small-scale fishermen tend not to register their boats or to apply for fishing licenses. Finally, unlike housing assistance, there was no explicit government policy with regard to the targeting and the allocation of boats.

This article focuses on the allocation process of these two major programmes relating to the affected fishing communities of Sri Lanka. With the help of an original data set, we first examine the implications of the allocation of new houses and new boats in these communities in terms of distribution. We then investigate the household determinants of the amounts of aid received. We focus on the targeting performance in terms of 'compensation' to replace assets for those who suffered damage, along the lines of a 'house for a house and a boat for boat'. The question is whether the intervention successfully restored the asset distribution that prevailed before the disaster in these communities. Thus we can draw some implications regarding the changes in the overall distribution of assets within these communities. We show that, while the allocation of new houses can be considered fair overall, and actually led to a more equal distribution of housing facilities, the allocation of boats was much more skewed and mistargeted, both in terms of actual ownership and in terms of boat values. Overall, both programmes favoured households that were members of community-based organisations, and households that did not experience human losses. Marginalised individuals who also suffered deaths and injuries in their families were clearly disadvantaged in the allocation of aid and the resulting asset ownership.

An interesting feature of our data set is that, while almost all households saw their homes damaged or destroyed, not all of them owned a boat, and were therefore differently affected by the tsunami. There is very little literature on the targeting of asset transfers in post-disaster situations in which households are affected very differently. The literature on social transfers, particularly food aid, usually suggests that such transfers are not always effective in targeting the poor, with large spatial disparities at the expense of the poorest communities (see, for example, Barrett, 2002; Galasso and Ravallion, 2000; and Jayne et al., 2002). We adopt a similar focus, but investigate instead transfers of high value assets in a postdisaster situation. By their nature, these transfers may be harder to properly target and insulate from various manipulations and external influences.

The rest of the article is organised as follows: section 2 presents the study area and the data collection process; section 3 investigates the allocation of housing aid; section 4 examines the targeting of the boat programme; and the conclusion is provided in section 5 .

\section{Description of the study area and data collection}

The 2004 tsunami affected 13 coastal districts in Sri Lanka, with eight being severely affected. Due to security issues, we had to drop two districts from our survey, so that our analysis covers the following six districts: Galle, Matara and Hambantota in the Southern Province, and Batticaloa, Trincomalee and Ampara in the Eastern Province. 
Our baseline data come from the Tsunami Census conducted by the Department of Census and Statistics in 2005, which provides information on the socioeconomic conditions (household composition, housing conditions, main activity) prevailing before the tsunami, as well as the damages caused by the tsunami (death and injuries and loss of or damage to houses). We conducted an original follow-up survey in 2008 on a stratified random sample of 390 fishing households from the set of households covered in the original census. In the six districts studied, we identified all the divisions (that is to say, villages) with at least $5 \%$ of fishing households, and randomly selected 39 of them. We then randomly selected ten households in each division (see Appendix 1). ${ }^{5}$

The questionnaire focused on the post-tsunami socioeconomic situation as well as the sources and amount of aid received. We also collected detailed recall data on pre-tsunami boat ownership from these households, as the census did not record that information. This is recall information, which may be biased. Given that these are large assets (fishing assets), households have proper information for this, but may tailor their answer within the context of the aid interventions (see, for instance, Mullan et al., 2014). To avoid bias, we cross-checked the information reported with the Census of Fishing Boats conducted by the Ministry of Fisheries and Aquatic Resources in 2006/2007 (MFAR, 2008). We complemented these questionnaires with qualitative interviews with key informants (fishery inspectors, Grama Niladhari, ${ }^{6}$ representatives of fishery co-operatives, etc.) as well as focus group discussions with members of the fishing communities. Gathering all these sources facilitated accurate information relating to boat ownership among our sampled households.

\section{House ownership and aid targeting}

As stated above, the housing programme was one of two major interventions in the area. In our sample, $93 \%$ of the households owned a house before the tsunami, with $65 \%$ of them living in permanent and $28 \%$ in temporary structures. ${ }^{7}$ Given the proximity to the sea, all houses were damaged, with $71 \%$ of them fully damaged. In $2008,83 \%$ of the households owned a permanent house, while $4 \%$ lived in a temporary lodging. About half of them rebuilt their houses, while the other half $(43 \%)$ were relocated to a new house.

Among all households, $82 \%$ actually received housing aid from the government $(64 \%)$ or the NGOs $(63 \%)$, with $45 \%$ of the households receiving aid from both sources. Unfortunately, we could not collect accurate information on the actual amount of aid received for housing. We therefore decided to compute the value of the house based on its characteristics and construction date for the pre- and the post-tsunami houses, using the guidelines provided by the Urban Development Authority (see details in Appendix 1). The value of a house in 2008 was on average

5. The characteristics of the sample drawn for the follow-up survey are very similar to the characteristics of the population covered by the census.

6. Grama Niladhari is the official designation of the village officer.

7. This distinction is based on the materials used for construction (see Appendix 1 for details).

(C) The Authors 2016. Development Policy Review (C) 2016 Overseas Development Institute.

Development Policy Review 34 (2) 
equal to Rs. 570,088 , more than double the pre-tsunami value (Rs. 265,555 ). ${ }^{8}$ The amount of housing aid represents an important part of this value as the state grant for fully damaged houses was initially Rs. 250,000, which corresponds to roughly $50 \%$ of the current value of a house. This amount does not include transfers and housing aid provided by NGOs, over which we have no reliable information.

When providing aid, correctly identifying the beneficiaries is a challenging task, which tends to suffer from two types of mistargeting: errors of exclusion, by missing the intended beneficiaries, and errors of inclusion, by providing benefits to non-needy individuals (Barrett, 2002; Besley and Kanbur, 1990). However, these measures do not take into account the amounts involved in the transfers, and therefore ignore their broader distributional implications (Coady et al., 2004). We go one step further by also examining the complete distribution of home ownership. Finally, we provide a brief multivariate household analysis of the targeting of housing aid in order to identify additional characteristics that may have influenced the allocation of aid.

Following the government guidelines, the donors set the amount of aid on the basis of a standard housing unit. As a result, most of the relocated households received a standard house, independently of the status (permanent or temporary) or the value of their previous houses. For house repairs, the amount of aid given was defined as lump sum transfers based on the severity of the damage, and not on the actual value of the damages. Moreover, while initially housing aid was first allocated to pre-tsunami house owners, this policy was later extended to all affected families, including those presumably poorer households that had not owned a 'permanent' house before the tsunami. From a distributional point of view, these two factors should imply not only a more equitable distribution of houses among the population, as more families now have access to proper housing, but also a more equitable distribution of house values among homeowners, because of the lump sum nature of the transfers.

In Table 1 we present the distribution of households according to their present and past house ownership along with access to housing aid.

$93 \%$ of the households had owned a house before the tsunami, and all houses were damaged. The remaining $7 \%$ did not own a house and lived either with relatives or in temporary shelters on government reservations (mostly marine reserves). In 2008, the percentage of house-owners had fallen to $87 \%$. The extent of mistargeting is very limited. Among the entire population, $81 \%$ of households had a house and received housing aid and only $12 \%$ of former homeowners did not receive aid, of whom $5 \%$ built or repaired their houses on their own and presumably belong to relatively wealthier strata of the population. The remaining $7 \%$ correspond to households who had built a house on land (typically state land) that did not belong to them. Very few (around 1\% of the population) households that did not own a house before the tsunami had access to housing aid and currently own a house. Most of them (around $6 \%$ of the population) remained homeless, living in non-permanent huts.

8. These numbers are all given in 2008 constant prices.

(C) The Authors 2016. Development Policy Review (C) 2016 Overseas Development Institute. Development Policy Review 34 (2) 
Table 1: Past and present house ownership and access to housing aid

\begin{tabular}{lcccccc}
\hline & & \multicolumn{2}{c}{$\begin{array}{c}\text { Current house } \\
\text { owner }\end{array}$} & \multicolumn{2}{c}{$\begin{array}{c}\text { Received } \\
\text { housing aid }\end{array}$} & Total \\
& & Yes & No & Yes & No & \\
\hline Pre-tsunami house ownership & Yes & 339 & 30 & 322 & 47 & 369 \\
& & $(86 \%)$ & $(7 \%)$ & $(81 \%)$ & $(12 \%)$ & $(93 \%)$ \\
& No & 4 & 23 & 3 & 24 & 27 \\
& & $(1 \%)$ & $(6 \%)$ & $(1 \%)$ & $(6 \%)$ & $(7 \%)$ \\
& Total & 342 & 53 & 325 & 71 & 396 \\
& & $(87 \%)$ & $(13 \%)$ & $(82 \%)$ & $(18 \%)$ & \\
\hline
\end{tabular}

The cumulative distribution curve of house values presented in Figure 1 reflects the large increase in house values that followed the reconstruction. With the exception of the bottom 7\% of families who lost their houses and could not get access to a new one (at the very left of the curve), the current distribution strongly dominates the pre-tsunami distribution. For instance, while about $75 \%$ of the population had houses with a value inferior to Rs. 400,000, this proportion fell to $30 \%$ in 2008.

Figure 2 presents the Lorenz curves for the distribution of house values before and after the tsunami, and indicates much less inequality in the distribution (with the exception of a few households who became homeless with no access to aid). As a result, the Gini coefficient falls from 0.50 to 0.43 .

\section{Figure 1: Cumulative distribution curves for pre-tsunami and current house values}

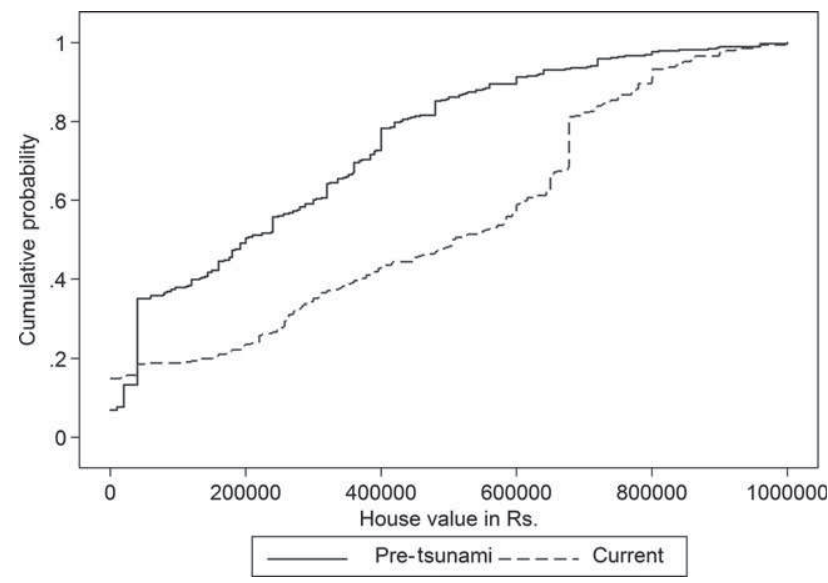

(C) The Authors 2016. Development Policy Review (C) 2016 Overseas Development Institute. Development Policy Review 34 (2) 


\section{Figure 2: Lorenz curves for pre-tsunami (hv[2004]) and current house values (hv[2008])}

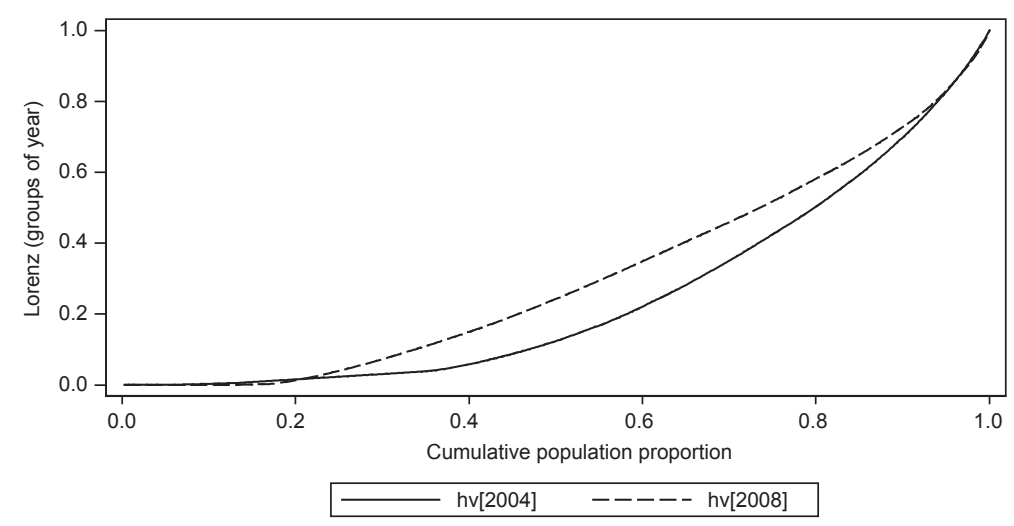

Given that the housing situation appears much more equitable in 2008 than in 2004 , it is worth investigating whether the allocation of housing aid favoured particular segments of the population. Among the relevant household characteristics, we focus in particular on whether a member of the household was killed or injured by the tsunami and whether the household head was a member of the local Community Based Organisation (CBO) in 2004. We also control for the age, gender and education of the household head, as well as district fixed effects. These estimations provide us with interesting correlations, but may suffer from several omitted variable biases which weaken causal interpretations. In particular, these characteristics, such as being a $\mathrm{CBO}$ member or being more susceptible to tsunami damage (for instance, by living closer to the seashore), are not randomly allocated or exogenous. They are correlated with one's position in the local community, personal dynamism and other factors that we do not measure, but which may imply a better ability to defend one's own rights and attract aid. We suggest in the following discussions plausible mechanisms underlying the observed correlations. The relevant descriptive statistics are provided in Appendix 2. The results of these estimations are given in Table 2.

In column (1), the dependent variable is the probability for a particular household to have received housing aid. The resulting current house ownership is examined in column (2). As discussed above, pre-tsunami house owners are much more likely to receive housing aid and to currently own a house. More interestingly, while most of the characteristics attached to the household head are not significant, former membership of the local community organisation increases the probability of receiving aid or owning a house by 9 percentage points. This effect may be the result of stronger local connections, but may also be due to the strategies used by the donor agencies themselves. According to our field surveys, many of them directly approached community-based organisations in order to obtain reliable information on their potential beneficiaries. This strategy is likely to have favoured members of these organisations in their access to the housing programmes. 


\begin{tabular}{|c|c|c|c|c|c|}
\hline \multicolumn{6}{|c|}{ Table 2: Determinants of access to housing aid and current house values } \\
\hline Dependent variable & $\begin{array}{l}\text { Recipient of } \\
\text { housing aid } \\
\text { (1) }\end{array}$ & $\begin{array}{l}\text { Current house } \\
\text { ownership } \\
\text { (2) }\end{array}$ & $\begin{array}{c}\text { Current } \\
\text { house value } \\
\text { (3) }\end{array}$ & $\begin{array}{c}\begin{array}{c}\text { Current house } \\
\text { value (rebuilt } \\
\text { households) } \\
\mathbf{n}=\mathbf{2 0 2}\end{array} \\
\end{array}$ & $\begin{array}{c}\text { Current house value } \\
\text { (relocated households) } \\
\text { n=160 }\end{array}$ \\
\hline Pre-tsunami house ownership & $0.77 * * *(0.080)$ & $0.79 * * *(0.080)$ & & & \\
\hline Pre-tsunami land ownership & $0.046(0.049)$ & $0.054(0.041)$ & & & \\
\hline Pre-tsunami house value & & & $0.21^{* * *}$ & $0.26^{* *}$ & -0.06 \\
\hline Male head & $0.023(0.096)$ & $0.007(0.073)$ & -62092.18 & -13626.41 & -38389.61 \\
\hline Age of the head & $0.0003(0.0087)$ & $-0.003(0.066)$ & 6407.87 & 11412.90 & 8936.73 \\
\hline Primary education of the head & $-0.1078(0.073)$ & $-0.012(0.047)$ & 7361.09 & 46899.37 & -115707.33 \\
\hline Secondary education of the head & $-0.017(0.047)$ & $0.026(0.046)$ & 21843.36 & 43608.76 & -80151.37 \\
\hline Death in the family & $-0.044(0.064)$ & $-0.036(0.056)$ & $-91763.65^{*}$ & -63951.13 & -48927.59 \\
\hline Injured member in the family & $-0.009(0.07)$ & $-0.027(0.062)$ & $-106732.57^{*}$ & -79131.96 & -116795.73 \\
\hline Membership of a $\mathrm{CBO}$ & $0.087 * *(0.041)$ & $0.094 * *(0.035)$ & 42885.23 & -19401.88 & $125790.72^{* *}$ \\
\hline
\end{tabular}

Notes: Columns (1) and (2) were estimated using a probit model, columns (3)-(5) using a Tobit model. Marginal effects are reported. District fixed effects are included in all the estimates. $* * *, * *, *$ denote significance at the 1,5 and $10 \%$ levels respectively. (a) 53 left-censored observations at current house value $<=0$ and 343 uncensored observations. 
Columns (3) to (5) report the results of the estimations when the current value of the house is taken as the dependent variable, with columns (4) and (5) reporting separately the estimates for households who rebuilt their houses and those who were relocated in the village. First, it is interesting to note that the coefficient attached to the pre-tsunami value of the house is much smaller than one. This reflects the fact that the current distribution of house values is much flatter or more equitable than before. For relocated households, the government guidelines seem to have been strictly followed, since the estimated coefficient is simply nil. Second, on average households which suffered personal losses were not advantaged in their access to housing aid, and currently own houses of lower value on average. Our field observations reveal that families that experienced death or injury during the tsunami focused less on obtaining aid and more on mourning, organising funerals and religious rituals, and looking after the injured. Finally, in terms of house values, CBO members seem to be advantaged only when they were relocated, but not when they kept their former house. The district fixed effects (not reported here) indicate regional disparities, with higher value houses in Hambantota and Galle. These two southern districts are located closer to Colombo (and further from the zones of highest civil war conflict), and also enjoy better infrastructure facilities, which made access to the affected communities easier.

\section{Boat ownership and aid targeting}

Before the tsunami, $46 \%$ of households owned a boat. Of these, $39 \%$ completely lost their boats, $6 \%$ had their boats totally destroyed and only $1 \%$ suffered no damage. Currently $38 \%$ of households own a boat, and $31 \%$ of households received boat aid, mostly from NGOs (which directly helped $25 \%$ of the households as compared to $5 \%$ from the Government and $1 \%$ from other sources).

In the household survey, we collected detailed information on the value and the technical characteristics of the boats. The current value of a boat is equal to Rs. 122,444, while the average value of the boats owned before the tsunami was much lower, equal to Rs. 83,597 (in 2008 prices). ${ }^{9}$ The average value of the boats effectively destroyed is also lower, equal to Rs. 63,498, as smaller boats were more likely to be affected by the tsunami. In comparison, the average amount of boat aid received per boat was equal to Rs. 99,703.

In Table 3, we present the distribution of boat ownership in 2004 and 2008. The figures are striking: out of the 184 pre-tsunami boat owners, only 109 (59\%) currently own a boat. By contrast, among the 212 households that did not own a boat, 42 succeeded in owning a boat in 2008. Of course, these changes may be due to some normal reallocation of ownership among fishermen. However, from our field surveys, many informants complained about the poor targeting of the boat aid, with new boats being given to households that had no boats prior to the tsunami, or whose boats were not damaged. By contrast, former boat owners who lost their boats were often forced to find a new occupation as crew member, fish trader or in

9. Boat values were later cross-checked with the values given by the Ministry of Fisheries and private boatyards, on the basis of the type and the age of the boat. We also assumed an annual depreciation rate for boats equal to $5 \%$.

(C) The Authors 2016. Development Policy Review (C) 2016 Overseas Development Institute.

Development Policy Review 34 (2) 
temporary construction work. In Table 4, we present the distribution of boat aid among fishermen.

Table 3: Changes in the distribution of boat ownership

\begin{tabular}{lcccc}
\hline & & \multicolumn{2}{c}{ Current boat owner } & Total \\
& & Yes & No & \\
\hline Pre-tsunami boat owner & Yes & 109 & 75 & 184 \\
& & $(28 \%)$ & $(19 \%)$ & $(46 \%)$ \\
& No & 42 & 170 & 212 \\
& & $(11 \%)$ & $(43 \%)$ & $(54 \%)$ \\
& Total & 151 & 243 & 396 \\
& & $(39 \%)$ & $(62 \%)$ & \\
\hline
\end{tabular}

Table 4: Distribution of boat aid

\begin{tabular}{lcccc}
\hline & & \multicolumn{2}{c}{ Aid received } & Total \\
& & Yes & No & \\
\hline Boat destroyed & Yes & 74 & 80 & 154 \\
& & $(19 \%)$ & $(20 \%)$ & $(39 \%)$ \\
& No & 49 & 193 & 242 \\
& Total & $(12 \%)$ & $(49 \%)$ & $(61 \%)$ \\
& 123 & 273 & 396 \\
& $(31 \%)$ & $(69 \%)$ & \\
\hline
\end{tabular}

The extent of misallocation of boat aid is striking. More than half of the fishermen who actually lost their boats did not receive aid, while $20 \%$ of the households that either did not own a boat or did not suffer major damage actually received aid. These figures indicate poor targeting of boat aid.

The amounts given under boat aid were also large, which suggests that the allocation of boat aid was relatively skewed. In Figure 3, we present the cumulative distribution of the value of the boats destroyed and the amounts received under the aid programme. It appears that two types of boat aid were given out: a small lump sum of about Rs. 30,000 , or a very large amount, superior to Rs. 300,000 , which corresponds to larger and more expensive crafts than those owned previously. As a result, while some fishermen who received aid were only poorly compensated, if at all, others succeeded in having access to very large amounts. In Figure 4, we present the cumulative distribution of current boat values, which follows very closely that of the amounts of aid received. The allocation of aid therefore appears as a major determinant of the current distribution of boat ownership.

(C) The Authors 2016. Development Policy Review (C) 2016 Overseas Development Institute. Development Policy Review 34 (2) 


\section{Figure 3: Cumulative distribution curves for the value of the boats destroyed and the amounts of boat aid received}

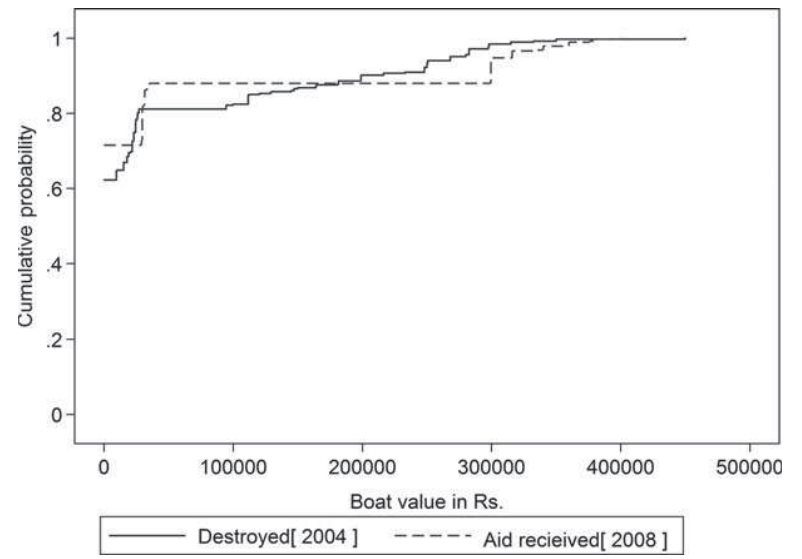

Figure 4: Cumulative distribution curves for current and pre-tsunami boat values

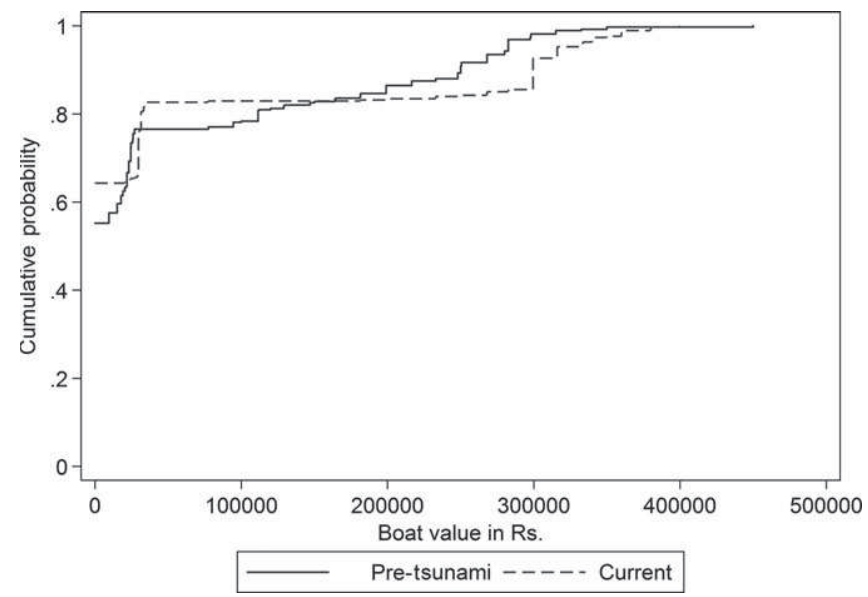

Because of these changes, the resulting distribution of boat values among the population is much more unequal than the one that previously prevailed. Figure 5 presents the Lorenz curve for the distribution of boat ownership. As the Figure indicates, inequality in boat ownership is much larger now than in the past, both because fewer households currently own a boat, and also because the current value of the boats is much larger. The Gini coefficients increased from 0.81 to 0.86 in the process.

We again investigate the determinants of access to aid and current ownership at the household level. The estimates are presented in Table 5. Four results are worth emphasising here. First, the compensation given to pre-tsunami boat owners was 


\section{Figure 5: Lorenz curves for pre-tsunami (bv[2004]) and current boat values (bv[2008])}

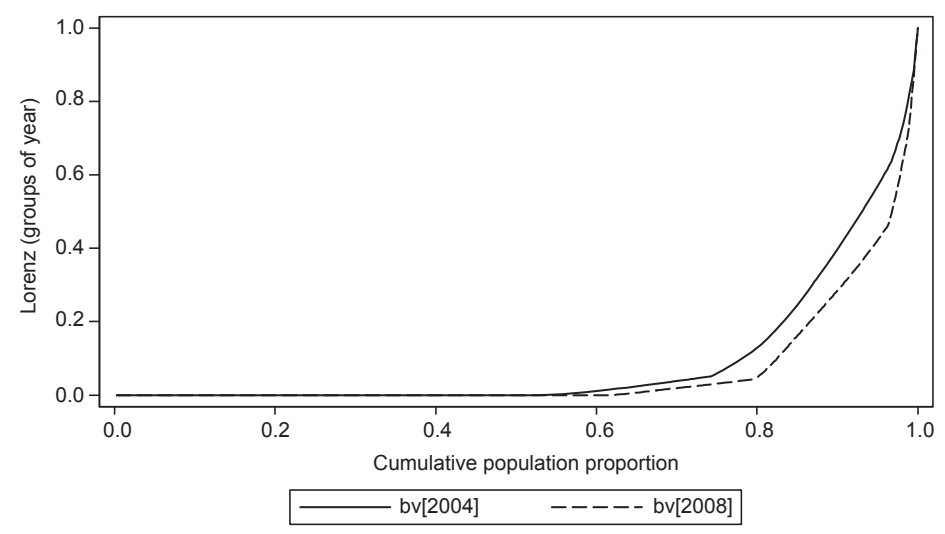

only partial, both in terms of access to aid and the amounts received. A one rupee increase in the initial value of the destroyed boat corresponds to a boat aid of only Rs. 0.42 (see col. (3)). Second, it appears again that households that lost a member are less likely to own a boat in 2008, possibly because the deceased member was also the operator of the boat. Third, members of fishery co-operatives enjoy a strong advantage in their access to aid, the amount of aid received and their current boat ownership, irrespective of whether they owned a boat previously. Again, it is likely that NGOs in charge of the boat aid mostly focused on these co-operatives to identify potential beneficiaries. Finally, the district fixed effects (not reported here) indicate that the district of Batticaloa was particularly advantaged in the process. Belonging to that district increased the probability of receiving aid or being a boat owner in 2008 by 16 percentage points.

\section{Concluding comments}

Boat and housing aid were the two major programmes put in place in the post-tsunami fishery communities of Sri Lanka. In terms of housing, we find that the distribution of new houses and housing aid resulted in a better distribution of houses. With the exception of the bottom end of the distribution, most households own better houses and their distribution is more egalitarian. In contrast, our results for the allocation of boat aid are very different. The distribution of new boats did not properly target former owners, and the value of these new boats is more skewed, so that the current distribution of boats is appreciably more unequal than that prevailing before the tsunami.

The difference between the two programmes is partly due to the nature of the asset, since house transfers and construction require more planning and a more coordinated effort compared to the transfers of boats. This may also explain why the government was mostly in charge of the housing programmes under clear policy guidelines, while boat programmes were implemented mostly by the NGOs, with no 
clear policy regarding their distribution. Moreover, information on former housing was easier to acquire than information on boat ownership.

\section{Table 5: Determinants of access to boat aid and current boat values}

\begin{tabular}{|c|c|c|c|c|}
\hline Dependent Variable & $\begin{array}{c}\text { Received } \\
\text { boat aid } \\
(1)\end{array}$ & $\begin{array}{c}\text { Current boat } \\
\text { ownership } \\
\text { (2) }\end{array}$ & $\begin{array}{l}\text { Amount of boat } \\
\text { aid received } \\
\text { (3) }\end{array}$ & $\begin{array}{c}\text { Current value } \\
\text { of the boat } \\
\text { (4) }\end{array}$ \\
\hline $\begin{array}{l}\text { Pre-tsunami boat owner } \\
\text { who lost boat }\end{array}$ & $\begin{array}{l}0.26 * * * \\
(0.05)\end{array}$ & & & \\
\hline Pre-tsunami boat owner & & $\begin{array}{l}0.38 * * * \\
(0.05)\end{array}$ & & \\
\hline $\begin{array}{l}\text { Current value of the } \\
\text { destroyed boat }\end{array}$ & & & $0.42 * * *$ & \\
\hline $\begin{array}{l}\text { Current value of the pre- } \\
\text { tsunami boat }\end{array}$ & & & & $0.48 * * *$ \\
\hline Male head & $\begin{array}{c}0.03 \\
(0.13)\end{array}$ & $\begin{array}{l}-0.06 \\
(0.145)\end{array}$ & 33634.29 & -27552.83 \\
\hline Age of the head & $\begin{array}{c}0.00 \\
(0.01)\end{array}$ & $\begin{array}{c}-0.002 \\
(0.014)\end{array}$ & -2945.09 & -21.49 \\
\hline $\begin{array}{l}\text { Primary education of the } \\
\text { head }\end{array}$ & $\begin{array}{c}0.04 \\
(0.08)\end{array}$ & $\begin{array}{l}0.04 \\
(0.086)\end{array}$ & 23575.58 & 31859.76 \\
\hline $\begin{array}{l}\text { Secondary education of the } \\
\text { head }\end{array}$ & $\begin{array}{r}-0.12 * \\
(0.06)\end{array}$ & $\begin{array}{l}-0.09 \\
(0.069)\end{array}$ & -58066.79 & -43892.62 \\
\hline Death in the family & $\begin{array}{l}-0.08 \\
(0.07)\end{array}$ & $\begin{array}{l}-0.14 * * \\
0.06908\end{array}$ & -41500.45 & -39144.62 \\
\hline $\begin{array}{l}\text { Injured member in the } \\
\text { family }\end{array}$ & $\begin{array}{c}0.01 \\
(0.08)\end{array}$ & $\begin{array}{l}0.07 \\
(0.088)\end{array}$ & 16377.38 & 34096.46 \\
\hline $\begin{array}{l}\text { Member of a fishery co- } \\
\text { operative }\end{array}$ & $\begin{array}{l}0.11^{* *} \\
(0.05)\end{array}$ & $\begin{array}{l}0.11^{*} \\
(0.055)\end{array}$ & $55270.59 *$ & $48451.10^{*}$ \\
\hline
\end{tabular}

Notes: Columns (1) and (2) were estimated using a probit model, columns (3) and (4) using a Tobit model. Marginal effects are reported. District fixed effects are included in all the estimates. ***, **,* denote significance at the 1,5 , and $10 \%$ levels respectively.

We also showed that both programmes were biased in favour of members of local community organisations. This reflects both the fact that members were privileged in accessing aid as compared to non-members within the same village, and also the fact that villages with more active local organisations were better able to mobilise external aid. We also find that families that experienced injuries or death did not succeed in receiving as much aid as the others. This suggests that donors should make a particular effort in post-disaster situations to target particular subsets of potential beneficiaries, such as the marginalised or those worst affected.

Finally, it is interesting to compare the distribution of these two main assets within the population before and after the tsunami. This is what we do in Figure 6, in which we add for each household the value of the house and the boat owned both in 2004 and in 2008: 


\section{Figure 6: Cumulative distribution curves for the pre-tsunami and the current total asset value}

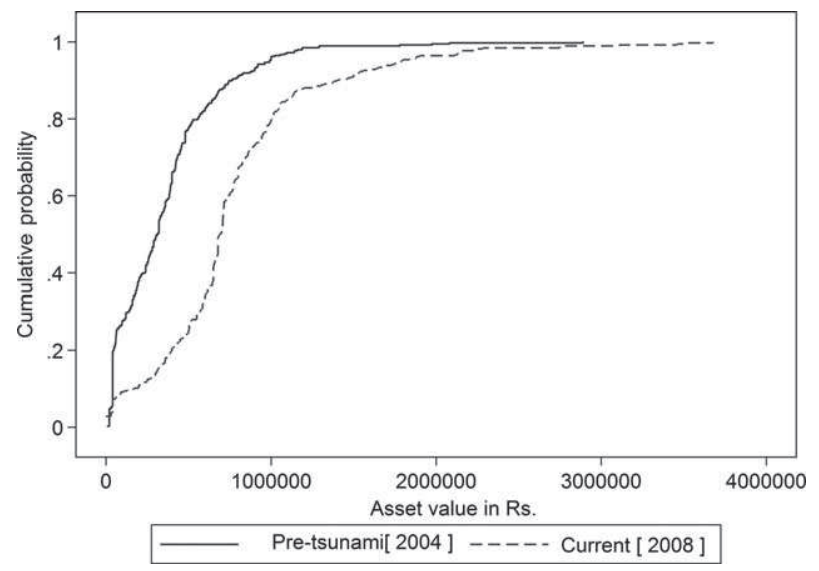

With the exception of the very bottom of the distribution, households currently enjoy a much better position in terms of total asset ownership. The distribution is also more egalitarian. This is due to both the large scale and the inclusive nature of the housing programme and the higher value of a house, so that the equalising effects of the housing programme largely dominated the distortions introduced by the boat programme in terms of the overall distribution of assets.

first submitted May 2012

final revision accepted November 2015

\section{References}

Amarasinghe, O. (2006) 'An Assessment of the Post-Tsunami Recovery Process in the Fisheries Sector of Sri Lanka: Sri Lanka country report', ICSF PostTsunami Rehabilitation Workshop Proceedings, 18-19 January, Chennai, India.

Barrett, C. B. (2002) Food Aid Effectiveness: It is the targeting, stupid! Applied Economics and Management Working Paper No. 2002-43. Ithaca, NY: Department of Applied Economics and Management, Cornell University.

Besley, T. and Kanbur, R. (1990) The Principles of Targeting. Working Paper WPS385. Washington, DC: World Bank.

Coady, D., Grosh, M. and Hoddinott, J. (2004) Targeting of Transfers in Developing Countries: Review of lessons and experience. Washington, DC: World Bank and International Food Policy Research Institute (IFPRI).

DCS (2005) Atlas on the Buildings Affected by the Tsunami-2004. Colombo, Sri Lanka: Department of Census and Statistics. 
Galasso, E. and Ravallion, M. (2000) Distributional Outcomes of a Decentralized Welfare Program. Working Paper No. 2316. Washington, DC: Development Research Group, World Bank.

GOSL (2005) Sri Lanka: Post-tsunami recovery and reconstruction. Joint Report of the Government of Sri Lanka and Development Partners. Colombo, Sri Lanka: Government of Sri Lanka.

ICSFW (2005) SAMUDRA: Triennial Report of the International Collective in Support of Fish Workers. Brussels: International Collective in Support of Fishworkers.

IPS (Institute of Policy Studies of Sri Lanka) (2006) Post-tsunami Reconstruction and Rehabilitation: Household views on progress and process. Draft Report. Colombo, Sri Lanka: Institute of Policy Studies of Sri Lanka and Mandaluyong, Philippines: Asian Development Bank.

Jayne, T. S.; Strauss, J.; Tamano, T. and Molla, D. (2002) 'Targeting of Food Aid in Rural Ethiopia: Chronic need or inertia?', Journal of Development Economics 68(2): $247-88$.

Mavrotas, G. (2009) 'Introduction: Development aid-theory, policies and performance', Review of Development Economics 13(3): 373-81.

MFAR (Ministry of Fisheries and Aquatic Resources) (2008) Census of Fishing Boats 2006/2007. Colombo, Sri Lanka: Ministry of Fisheries and Aquatic Resources.

MFAR (2006) 'Recovery Assessment in the Fisheries Sector'. Draft Report. Colombo, Sri Lanka: Ministry of Fisheries and Aquatic Resources.

Mullan, K., Sills, E. and Bauch, S. (2014) 'The Reliability of Retrospective Data on Asset Ownership as a Measure of Past Household Wealth', Field Methods 26(3): 223-38.

Slater, R. and Farrington, J. (2009) Targeting of Social Transfers: A review for DFID. London: Overseas Development Institute.

\section{Appendix 1: Sampling design and mode of valuation of the houses}

Table A1 describes per district the sampling used for the original survey.

We now describe the procedure followed for the valuation of the houses. For each house, we collected information on the materials used for the roof, the floor and the walls, the total area of the floor, the number of rooms and the date of construction. This information is used to classify houses as permanent or temporary.

For new permanent houses, we apply the Urban Development Authority price scale, with a rate of Rs. 1,000 per square foot in 2005 , Rs. 1,100 in 2006, Rs. 1,300 in 2007 and Rs. 1,500 in 2008. For current temporary houses, we estimated temporary houses with a floor area of between $250-500 \mathrm{ft}^{2}$ at Rs. 40,000 , houses with less than $250 \mathrm{ft}^{2}$ at Rs. 20,000 and houses with more than $500 \mathrm{ft}^{2}$ floor area at Rs. 60,000.

For the pre-tsunami permanent houses, we apply a rate of Rs. 1,000 per square foot, and then apply the following depreciation rates: 
Table A1: Sampling design of the original survey

\begin{tabular}{|c|c|c|c|c|}
\hline District & $\begin{array}{l}\text { No. of selected } \\
\text { DSDs }^{\text {a }}\end{array}$ & Selected DSDs & $\begin{array}{l}\text { No. of } \\
\text { GNDs }\end{array}$ & $\begin{array}{l}\text { No. of fisher } \\
\text { households }\end{array}$ \\
\hline \multirow[t]{2}{*}{ Galle } & 2 & Hikkaduwa & 3 & 30 \\
\hline & & Balapitiya & 3 & 30 \\
\hline Matara & 1 & Weligama & 3 & 30 \\
\hline Hambantota & 1 & Hambantota & 3 & 30 \\
\hline \multirow[t]{4}{*}{ Batticaloa } & 4 & Koralaipattu North & 3 & 30 \\
\hline & & Valachchenai & 3 & 30 \\
\hline & & Manmunnai north & 3 & 30 \\
\hline & & Manmunnai south & 3 & 30 \\
\hline \multirow[t]{2}{*}{ Ampara } & 2 & Kalmunai & 3 & 30 \\
\hline & & Pothuvil & 3 & 30 \\
\hline \multirow[t]{3}{*}{ Trincomalee } & 3 & Town \& Gravets & 3 & 30 \\
\hline & & Kinniya & 3 & 30 \\
\hline & & Kuchchaveli & 3 & 30 \\
\hline Total & 13 & & 39 & 390 \\
\hline
\end{tabular}

Notes: (a) DSD is Divisional secretariat divisions. (b) GND is Grama Niiladhari divisions (i.e., villages).

Table A2: Depreciation scale applied for the pre-tsunami permanent houses

\begin{tabular}{lc}
\hline Age Category & Depreciation \\
\hline$<10$ & $20 \%$ \\
$10-25$ & $40 \%$ \\
$25-50$ & $60 \%$ \\
$50-100$ & $80 \%$ \\
$>100$ & $80 \%$ \\
\hline
\end{tabular}

For pre-tsunami temporary houses, as $99 \%$ of the houses measured less than 500 square feet, we did not consider the floor area, and instead applied the following scale:

Table A3: Depreciation scale applied for the pre-tsunami temporary houses

\begin{tabular}{lc}
\hline Age Category & Value (Rs.) \\
\hline$<10$ & 40,000 \\
$10-25$ & 20,000 \\
$25-50$ & 10,000 \\
\hline
\end{tabular}

(C) The Authors 2016. Development Policy Review (C) 2016 Overseas Development Institute. Development Policy Review 34 (2) 


\section{Appendix 2}

Table A4: Descriptive statistics on household characteristics $(n=396)$

\begin{tabular}{lcc}
\hline & Mean value & $\begin{array}{c}\text { Standard deviation } \\
\text { (where relevant) }\end{array}$ \\
\hline Pre-tsunami house ownership & 0.93 & 250297 \\
Pre-tsunami value of a house & 265555 & 487089 \\
Current house ownership & 0.87 & \\
Current value of a house & 570088 & 0.71 \\
The house was fully damaged & 0.29 & \\
The house was partially damaged & 0.40 & \\
The household was relocated & 0.82 & \\
The household received housing aid & 0.46 & \\
Pre-tsunami boat ownership & 82596 & \\
Pre-tsunami value of a boat & 0.39 & 381358 \\
The boat was fully damaged & 0.06 & \\
The boat was partially damaged & 0.38 & \\
Current boat ownership & 122444 & 162779 \\
Current value of the boat & 0.31 & \\
The household received boat aid & 99703 & \\
Amount of boat aid received & 63498 & \\
Value of the destroyed boat & 0.96 & \\
Head is male & 45.42 & \\
Age of the household head & 0.19 & \\
Head has primary level education & 0.51 & \\
Head has secondary level education (or above) & 0.12 & \\
Household lost a member in the tsunami & 0.11 & \\
Household had a member injured by the tsunami & 0.64 & \\
Household is a member of a CBO & 0.53 & \\
Household is a member of a fishery co-operative & & \\
\hline
\end{tabular}

